\title{
PELAKSANAAN PEMBELAJARAN MENULIS TEKS PANTUN PADA SISWA KELAS VII SMPN 3 KOTA BENGKULU TAHUN PELAJARAN 2016/2017
}

\author{
Dewi Wulandari ${ }^{1}$, Susetyo $^{2}$, dan Amrizal ${ }^{3}$ \\ ${ }^{1,2,3}$ Program Studi Pendidikan Bahasa dan Sastra Indonesia \\ Jurusan Pendidikan Bahasa dan Seni \\ FKIP Universitas Bengkulu \\ Dewiwulandari173@yahoo.com
}

\begin{abstract}
Abstrak
Tujuan penelitian ini mendeskripsikan pelaksanaan pembelajaran menulis teks pantun siswa dan pelaksanaan penilaian teks pantun karya siswa kelas VII 2 SMPN 3 Kota Bengkulu. Metode yang digunakan dalam penelitian ini adalah metode deskriptif kualitatif. Subjek penelitian ini adalah guru yang sedang melaksanakan pembelajaran dan siswa yang sedang mengikuti pembelajaran menulis teks pantun di kelas VII 2 SMPN 3 Kota Bengkulu. Teknik pengumpulan data menggunakan observasi, wawancara, dan studi dokumen. Teknik analisis data yang digunakan adalah Miles dan Huberman yang meliputi reduksi data, penyajian data, verifikasi data, dan kesimpulan. Uji keabsahan data yang digunakan adalah triangulasi sumber. Hasil penelitian menunjukkan bahwa pelaksanaan pembelajaran menulis teks pantun di kelas VII 2 menggunakan pendekatan saintifik dan dilaksanakan berdasarkan Rencana Pelaksanaan Pembelajaran yang telah dibuat oleh guru. Guru melaksanakan penilaian teks pantun karya siswa diawali dengan memberikan petunjuk mengerjakan tugas untuk menulis pantun, siswa mengerjakan tugas dan mengumpulkan tugas, guru membaca dan menilai pantun karya siswa berdasarkan kriteria penilaian yang terdapat di dalam Rencana Pelaksanaan Pembelajaran. Berdasarkan penilaian tersebut diperoleh nilai rata-rata kelas sebesar 76,5.
\end{abstract}

\section{Kata Kunci: Pelaksanaan Pembelajaran, Menulis, Pantun}

\begin{abstract}
The purpose of this study describes the implementation of textbook writing pantun students and the implementation of text ratings pantun works of students of class VII 2 SMPN 3 Kota Bengkulu. The method used in this research is descriptive qualitative method. The subject of this research is the teacher who is carrying out the learning and the students who are following the pantun text writing lesson in class VII 2 SMPN 3 Kota Bengkulu. Data collection techniques used observation, interviews, and document studies. Data analysis techniques used are Miles and Huberman which include data reduction, data presentation, data verification, and conclusion. Test data validity used is source triangulation. The results showed that the implementation of pantun text writing lesson in class VII 2 using scientific approach and implemented based on the Implementation Plan of Learning that has been made by the teacher. Teachers carry out the assessment of the text of the students 'pantun begins by giving instructions on performing the task of writing the pantun, the students doing the tasks and collecting the task, the teacher reading and assessing the students' pantun based on the assessment criteria contained in the Lesson Plan. Based on the assessment, the grade averaged 76.5 .
\end{abstract}

Keywords: Implementation of Learning, Writing, Pantun 


\section{PENDAHULUAN}

Sastra memiliki fungsi penting dalam kehidupan manusia. Melalui sastra hidup akan terasa dinamis dan indah. Tidak dapat dipungkiri bahwa bersastra adalah salah satu cara manusia mengungkapkan segala imajinasinya menjadi sesuatu yang baru dan menarik. Tidak hanya sebuah karya yang didapatkan melalui sastra, tetapi juga kepuasan batin. Di dalam sastra juga terkandung nilai-nilai kehidupan yang dapat dipelajari dengan mengambil pesan baik yang disampaikan dan membuang nilai yang tidak baik. Oleh karena itu, sastra memiliki peran juga terhadap pembangunan karakter seseorang. Sastra sebagai salah satu media dalam membangun karakter seseorang perlu diajarkan di setiap jenjang pendidikan.

$\mathrm{Hal}$ tersebut sejalan dengan pendapat Horace (dalam Ismawati, 2013:3) bahwa sastra itu dulce et utile, artinya indah dan bermakna. Sastra sebagai sesuatu yang dipelajari atau sebagai pengalaman kemanusiaan dapat berfungsi sebagai bahan renungan dan refleksi kehidupan karena sastra bersifat koekstensif dengan kehidupan, artinya sastra berdiri sejajar dengan hidup. Dalam kesusastraan dapat ditemukan berbagai gubahan yang mengungkapkan nilai-nilai kehidupan, nilai-nilai kemanusiaan, nilainilai sosial budaya, di antaranya yang terdapat dalam puisi, prosa, dan drama.

Pengajaran sastra di jenjang pendidikan Sekolah Dasar (SD), Sekolah Menengah Pertama (SMP), dan Sekolah Menengah Atas (SMA) tidak diajarkan dalam mata pelajaran sastra tersendiri, tetapi terintegrasi langsung dalam pelajaran bahasa Indonesia, seperti puisi, drama, dan pantun. Teks-teks sastra diharapkan dapat dikuasai oleh siswa dengan baik. Penguasaan terhadap teks sastra tidak terjadi secara instan atau tibatiba, tetapi melalui proses pembelajaran yang terus-menerus. Berbagai upaya dilakukan oleh pihak sekolah untuk menumbuhkan kecintaan siswa terhadap sastra.

Kurikulum 2013 yang mulai diterapkan di beberapa sekolah yang ada di Provinsi Bengkulu mengajarkan tentang berbagai macam teks, salah satunya, yaitu teks pantun. Menurut Kurniasih dan Sani (2014:7), kurikulum 2013 merupakan serentetan rangkaian penyempurnaan terhadap kurikulum yang telah dirintis tahun 2004 yang berbasis kompetensi lalu diteruskan dengan kurikulum 2006 (KTSP). Menurut Mulyasa (2013:132) perubahan kurikulum diharapkan dapat menyelesaikan berbagai permasalahan yang sedang dihadapi oleh dunia pendidikan saat ini, terutama dalam memasuki era globalisasi yang penuh dengan berbagai macam tantangan.

Menurut Priyatni (2014:37), dalam Kurikulum 2013, bahasa Indonesia tidak hanya difungsikan sebagai alat komunikasi, tetapi juga sebagai sarana berpikir. Bahasa adalah sarana untuk mengekspresikan gagasan dan sebuah gagasan yang utuh biasanya direalisasikan dalam bentuk teks. Teks dimaknai sebagai ujaran atau tulisan yang bermakna, yang memuat gagasan yang utuh. Dengan asumsi tersebut, fungsi pembelajaran bahasa adalah mengembangkan kemampuan memahami dan menciptakan teks karena komunikasi terjadi dalam teks atau pada tataran teks. Pembelajaran berbasis teks inilah yang digunakan sebagai dasar pengembangan kompetensi dasar mata pelajaran bahasa Indonesia ranah pengetahuan dan keterampilan dalam Kurikulum 2013.

Dalam Kurikulum 2013 pembelajaran pantun harus mencapai KD 3.13 Mengidentifikasi informasi (pesan, rima, dan pilihan kata) dari puisi rakyat (pantun, syair, dan bentuk puisi rakyat setempat) yang dibaca dan didengar, KD 3.14 Menelaah struktur dan kebahasaan puisi rakyat (pantun, syair, dan bentuk 
puisi rakyat setempat) yang dibaca dan didengar, KD 4.13 Menyimpulkan isi puisi rakyat (pantun, syair, dan bentuk puisi rakyat setempat) yang disajikan dalam bentuk tulis dan lisan, dan KD 4. 14 Mengungkapkan gagasan, perasaan, pesan dalam bentuk puisi rakyat secara lisan dan tulis dengan memperhatikan struktur, dan aspek kebahasaan.

Berdasarkan pengamatan penulis, pembelajaran pantun juga berhubungan dengan kebutuhan sosial. Manusia hidup tidak dapat lepas dari masyarakat. Dengan pantun, siswa dilatih untuk memiliki seni dalam berbahasa untuk dapat mengungkapkan maksud dengan kata-kata yang indah. Pembelajaran pantun seharusnya mampu membuat siswa memiliki rasa sosial yang tinggi, khususnya ketika melakukan kegiatan berbalas pantun dengan rekan siswa yang lain. Selain itu, pesan yang disampaikan di dalam pantun juga biasanya adalah sebuah kepentingan sosial.

Dalam masyarakat kebiasaan berpantun diterapkan hanya di sebuah acara adat atau dalam pernikahan saja. Hal tersebut terjadi sudah dengan perencanaan dan proses latihan yang matang. Seseorang yang melakukan balas pantun sudah dipersiapkan sebelumnya sehingga terlihat sudah mahir dalam berpantun. Berbeda dengan seorang siswa di kelas yang diminta gurunya untuk berbalas pantun secara spontan akan merasa kesulitan karena kurang ada persiapan yang matang.

Kemampuan siswa dalam menulis pantun perlu diperhatikan. Jika siswa mampu menulis pantun dengan baik, hal tersebut menunjukkan bahwa pembelajaran berjalan dengan baik. Namun pada kenyataannya, kemampuan siswa dalam menulis teks pantun kurang memuaskan. Siswa kurang memiliki banyak perbendaharaan kosakata sehingga sulit mencari kata-kata yang sesuai untuk membuat sebuah teks pantun. Siswa juga kurang mampu berpikir kreatif mencari ide-ide baru yang menarik dalam membuat pantun, kebanyakan siswa membuat pantun yang bersifat monoton. Selain itu, ketidakmampuan siswa dalam menulis teks pantun dipengaruhi oleh ketidaksadaran siswa terhadap pentingnya materi tersebut. Banyak di antara siswa yang menganggap bahwa materi pantun tersebut tidak penting. Hal tersebut terbukti ketika diadakan sebuah lomba berbalas pantun, siswa banyak yang tidak tertarik untuk mengikutinya. Hal tersebut karena siswa tidak mampu dalam membuat atau menulis teks pantun dengan baik.

Berdasarkan pengamatan penulis, pembelajaran menulis teks pantun di SMPN 3 Kota Bengkulu perlu diperhatikan lagi. Letak sekolah yang tidak jauh dari pesisir pantai mempengaruhi karakteristik siswa yang pemberani dan keras. Pembelajaran di kelas sangat perlu disesuaikan dengan karakteristik peserta didik tersebut. Latar belakang budaya menjadi salah satu faktor kepribadian peserta didik. Guru perlu memperhatikan cara mengajar siswa yang memiliki karakter yang berani dan keras. Hal tersebut dapat dijadikan sebagai tantangan guru mengembangkan rasa kepercayaan diri siswa yang pada dasarnya sudah memiliki sikap berani untuk dapat mengembangkan kemampuan menulis teks pantun. Terlebih lagi apabila kemampuan menulis teks pantun tersebut dapat diterapkan langsung dalam kegiatan berbalas pantun yang membutuhkan rasa percaya diri dan kreativitas yang tinggi.

Selain itu, berdasarkan pengalaman penulis pembelajaran pantun kurang diperhatikan baik dari pihak guru maupun siswa. Tidak ada penekanan khusus dalam pembelajaran pantun. Setelah materi itu selesai diajarkan, siswa menganggap bahwa materi pantun kurang penting 
untuk dikembangkan. Kemampuan menulis teks pantun juga kurang mendapat perhatian khusus. Jika kemampuan menulis pantun itu baik, siswa dapat memperoleh manfaat dari pembelajaran menulis pantun tersebut.

Berdasarkan pemaparan di atas mengenai masalah yang terjadi dalam pembelajaran menulis pantun siswa, maka penelitian ini memiliki dua rumusan masalah yaitu (1) bagaimanakah pelaksanaan pembelajaran menulis teks pantun yang dilakukan guru bahasa Indonesia di kelas VII SMPN 3 Kota Bengkulu? dan (2) bagaimanakah penilaian guru terhadap hasil penulisan pantun siswa dalam pembelajaran menulis teks pantun di kelas VII SMPN 3 Kota Bengkulu? Adapun tujuan dari penelitian ini yaitu (1) untuk mendeskripsikan pelaksanaan pembelajaran menulis teks pantun yang dilakukan guru bahasa Indonesia di kelas VII SMPN 3 Kota Bengkulu dan (2) untuk mendeskripsikan penilaian guru terhadap hasil penulisan pantun siswa dalam pembelajaran menulis teks pantun di kelas VII SMPN 3 Kota Bengkulu.

\section{METODE}

Penelitian ini menggunakan metode deskriptif kualitatif. Metode deskriptif kualiatatif digunakan untuk mendeskripsikan pelaksanaan pembelajaran menulis teks pantun pada siswa kelas VII 2 SMPN 3 Kota Bengkulu dan penilaian guru terhadap hasil penulisan pantun siswa dalam pembelajaran menulis teks pantun di kelas VII SMPN 3 Kota Bengkulu.

Penelitian ini akan dilaksanakan pada tanggal 1 Februari 2017-1 Maret 2017 yang beralamat di Jalan Iskandar 474, Kelurahan Tengah Padang, Kecamatan Teluk Segara, Kota Bengkulu.

Data dalam penelitian ini yaitu kegiatan pelaksanaan pembelajaran menulis teks pantun yang akan dilaksanakan di kelas VII 2 SMPN 3 Kota Bengkulu berupa metode yang digunakan guru dalam mengajar, bahan pembelajaran yang digunakan, media yang digunakan oleh guru, dan cara penilaian guru. Sumber data dalam penelitian ini adalah kegiatan guru dan siswa dalam proses belajar mengajar bahasa Indonesia di dalam kelas VII 2 SMPN 3 Kota Bengkulu. Sumber data utama dalam penelitian kualitatif adalah kata-kata dan tindakan, selebihnya adalah data tambahan seperti dokumen. Jenis data dapat dibagi ke dalam kata-kata dan tindakan, sumber data tertulis, foto, dan rekaman.

Subjek penelitian ini adalah guru dan siswa kelas VII 2 SMPN 3 Kota Bengkulu yang sedang melaksanakan pembelajaran menulis teks pantun.

Instrumen penelitian dalam penelitian ini adalah sebagai alat penelitian utama. Peneliti sendiri yang akan melaksanakan observasi, mencatat, wawancara, dan studi dokumen.

Teknik pengumpulan data dilakukan dengan observasi, catat, wawancara, dan studi dokumen. Observasi dilakukan secara langsung untuk mengamati kegiatan guru dan siswa dalam melaksanakan pembelajaran menulis teks pantun dan mengamati permasalahanpermasalahan apa yang terjadi dalam pembelajaran menulis teks pantun tersebut. Untuk mendapatkan data yang objektif, observasi dilakukan pada waktu siswa mengikuti pembelajaran menulis teks pantun sebanyak dua kali untuk mengamati kegiatan-kegiatan siswa dalam belajar menulis teks pantun tersebut.

Teknik catat dilakukan peneliti untuk mengumpulkan data dengan mencatat proses pembelajaran pantun yang diamati. Peneliti mendengarkan dan mengamati proses pembelajaran dengan seksama agar diperoleh data yang akurat.

Wawancara dilakukan peneliti jika ingin mengetahui hal-hal dari responden 
yang lebih mendalam. Wawancara dilakukan terhadap guru dan siswa yang berkenaan dengan pelaksanaan pembelajaran menulis teks pantun. Wawancara yang peneliti gunakan dalam penelitian ini adalah wawancara terbuka, yaitu wawancara yang dilakukan pewancara dengan membawa sederetan pertanyaan dimana responden bebas memberikan informasi.

Dalam penelitian ini, dokumen yang digunakan untuk pengumpulan data yaitu tulisan-tulisan pantun siswa dan kemudian dianalisis oleh peneliti berdasarkan karakteristik penilaian pantun.

Teknik pengumpulan data sesuai dengan pendapat Miles and Huberman (dalam Sugiyono, 2014:246), mengemukakan bahwa aktivitas dalam analisis data kualitatif dilakukan secara interaktif dan berlangsung secara terus menerus sampai tuntas, sehingga datanya sudah jenuh.

Aktivitas dalam analisis data, yaitu data reduction, data display, dan conclusion drawing/verification. Keabsahan data diuji dengan menggunakan triangulasi sumber. Triangulasi sumber untuk menguji kredibilitas data dilakukan dengan cara mengecek data yang telah diperoleh melalui beberapa sumber. Sebagai contoh, untuk menguji kredibilitas data tentang perilaku murid, maka pengumpulan dan pengujian data yang telah diperoleh dapat dilakukan ke guru, teman murid yang bersangkutan dan orang tuanya. Data dari ketiga sumber tersebut tidak bisa dirataratakan seperti penelitian kuantitatif, tetapi dideskripsikan, dikategorikan, mana pandangan yang sama, yang berbeda, dan mana spesifik dari tiga sumber data tersebut. Data yang telah dianalisis oleh peneliti sehingga menghasilkan suatu kesimpulan selanjutnya dimintakan kesepakatan (member check) dengan tiga sumber tersebut.

\section{HASIL DAN PEMBAHASAN}

Berdasarkan hasil penelitian, pelaksanaan pembelajaran menulis teks pantun sudah berjalan dengan baik. Guru melaksanakan tugasnya sebagai pengajar dan siswa memerankan dirinya sebagai pelajar. Hal ini sesuai dengan pengertian pembelajaran menurut Abidin (2012:3) pembelajaran adalah serangkaian proses yang dilakukan guru agar siswa belajar. Dari sudut pandang siswa, pembelajaran merupakan proses yang berisi seperangkat aktivitas yang dilakukan siswa untuk mencapai tujuan belajar. Berdasarkan dua pengertian ini, pada dasarnya pembelajaran adalah serangkaian aktivitas yang dilakukan siswa guna mencapai hasil belajar tertentu dalam bimbingan dan arahan serta motivasi dari seorang guru.

SMPN 3 Kota Bengkulu sudah menerapkan Kurikulum 2013 sehingga pelaksanaan pembelajaran menggunakan pendekatan saintifik. Pelaksanaan pembelajaran menulis teks pantun di kelas VII 2 sudah dilaksanakan dengan menggunakan pendekatan saintifik. Hal tersebut dapat diamati ketika guru melaksanakan pembelajaran mulai dari awal pembelajaran, inti pembelajaran, dan akhir pembelajaran. Proses pembelajaran yang menyenangkan sangat berpengaruh terhadap keterlibatan siswa dalam proses pembelajaran yang berlangsung. Hal tersebut sejalan dengan pendapat Majid dan Rochmad bahwa langkah-langkah pendekatan saintifik di antaranya, mengamati, menanya, mencoba, mengolah, menyaji, menalar, dan mencipta. Tujuh aktivitas belajar tersebut merupakan aktivitas dalam mengembangkan keterampilan berpikir untuk mengembangkan ingin tahu siswa. Dengan itu diharapkan siswa termotivasi untuk mengamati fenomena yang terdapat di sekitarnya, mencatat atau mengidentifikasi fakta, lalu merumuskan 
masalah yang ingin diketahuinya dalam pernyataan menanya. Dari langkah ini diharapkan siswa mampu merumuskan masalah atau merumuskan hal yang ingin diketahuinya. Namun, pembelajaran di kelas VII 2 tidak menerapkan semua langkah dalam pembelajaran saintifik.

Pada awal pembelajaran, kegiatan mengamati menjadi langkah awal dalam memancing keterlibatan siswa untuk belajar. Guru berusaha membuat siswa agar dapat mengamati keadaan sekitar siswa. Kegiatan mengamati dapat terlihat ketika guru bertanya dimana kita masih menjumpai pantun. Para siswa langsung menjawab bahwa pantun sering dijumpai pada acara pernikahan. Hal tersebut dapat menjadi cara guru menerapkan langkah saintifik berupa mengamati. Selain itu, fungsi pertanyaan tersebut dapat juga sekaligus menerapkan apersepsi, yaitu mengaitkan materi dengan kehidupan sehari-hari siswa.

Guru menjelaskan materi menggunakan metode ceramah. Metode ini terkenal membosankan, seperti yang dikatakan oleh Hasibuan dan Moedjiono (2006:13) bahwa metode ceramah adalah cara penyampaian bahan pelajaran dengan komunikas lisan. Kelemahannya adalah bahwa siswa cenderung pasif, pengaturan kecepatan secara klasikal ditentukan oleh pengajar, kurang cocok untuk pembentukan keterampilan dan sikap, dan cenderung menempatkan pengajar sebagai otoritas terakhir. Namun, uniknya dalam pelaksanaan pembelajaran menulis pantun di kelas VII 2 SMPN 3 Kota Bengkulu, guru menggabungkan metode ceramah dengan metode tanya jawab di dalamnya sehingga siswa tetap terlibat dalam pembelajaran. Hal tersebut sesuai dengan pendapat Hasibuan dan Moedjiono (2016:14) bertanya memegang peranan yang penting, sebab pertanyaan yang tersusun baik dengan teknik pengajuan yang tepat akan meningkatkan pastisipasi siswa dalam kegiatan belajar mengajar, memnbangkitkan minat dan rasa ingin tahu siswa terhadap masalah yang sedang dibicarakan, mengembangkan pola berpikir dan belajar aktif siswa, menuntun proses berpikir siswa, dan memusatkan perhatian murid terhadap masalah yang sedang dibahas. Keaktifan siswa kurang terlihat, hanya bebrapa siswa saja yang memiliki keberanian untuk bertanya, seperti $M$. Hanif Nur Fajar.

Misalnya pada saat guru menjelaskan bahwa pantun merupakan kebudayaan melayu. Guru sambil menjelaskan juga memberikan pertanyaan kepada siswa untuk meminta siswa untuk menyebutkan ciri-ciri pantun, yaitu terdiri dari empat baris, setiap barisnya terdiri atas 8 sampai 12 suku kata, bersajak ab $a b$, baris pertama dan kedua disebut sampiran, baris ketiga dan keempat disebut isi yang mengandung pesan atau nilai yang ingin disampaikan di dalam pantun. Setelah siswa menjawab ciri-ciri pantun tersebut, guru menegaskan kembali ciri-ciri pantun yang sudah disebutkan oleh siswa. Guru juga mempersilahkan siswa untuk bertanya jika ada yang kurang jelas. Siswa dianggap paham mengenai ciri-ciri pantun sehingga guru langsung menjelaskan mengenai jenis-jenis pantun. setelah selesai menjelaskan mengenai jenis-jenis pantun, guru juga menjelaskan cara menyimpulkan isi puisi rakyat. Hal tersebut sesuai dengan KD 4.13 Menyimpulkan isi puisi rakyat.

Setelah guru selesai menjelaskan materi, guru membagi siswa menjadi beberapa kelompok dan diberi waktu untuk diskusi. Hal ini menjadi salah satu metode guru membuat siswanya belajar, khususnya belajar kerja sama dengan teman-temannya. Sejalan dengan yang disampaikan oleh Daryanto (2014:23) mengenai salah satu model pembelajaran dalam Kurikulum 2013 yaitu Pembelajaran Berbasis Proyek yaitu metode belajar yang 
menggunakan masalah sebagai langkah awal dalam mengumpulkan dan mengintegrasikan pengetahuan baru berdasarkan pengalamannya dalam beraktifitas secara nyata. . Pada pembelajaran pantun di kelas VII 2, guru memberikan lembar tugas kepada setiap kelompok berupa beberapa puisi lama dan siswa diminta untuk menentukan jenis puisi rakyat dan menganalisis berdasarkan cirinya. Guru membimbing kelompokkelompok kecil tersebut dengan berkeliling dan menanyakan kesulitan yang dihadapi oleh siswa. Setelah itu, setiap kelompok diminta untuk mempresentasikan hasil kerja kelompoknya.

Ketika guru selesai menjelaskan tugas yang harus dikerjakan oleh para siswa, ada salah satu siswa yang bertanya mengenai tugas tersebut. M. Hanif Nur Fajar bertanya kepada guru dengan sikap tenang dan percaya diri. Guru pun langsung menjawab pertanyaan Hanif dengan sabar.

Siswa mengerjakan tugas tersebut secara berkelompok dan berdiskusi dengan anggota kelompok yang telah dibentuk. Namun, waktu pembelajaran tidak cukup untuk melakukan presentasi. Kemudian guru memberikan tugas tambahan berupa tugas untuk menyimpulkan isi puisi rakyat secara berkelompok juga. Guru meminta siswa untuk mempresentasikan pada saat pertemuan berikutnya. Hal ini menunjukkan bahwa kurang efektifnya waktu pempelajaran yang digunakan guru dan siswa. Jika siswa mengerjakan dengan sungguh-sungguh, maka tugas tersebut akan selesai tepat waktu sesuai dengan rencana yang sudah direncanakan oleh guru.

Pada pertemuan berikutnya, guru membuka pembelajaran seperti biasa dengan mengkondisikan kelas dan mengecek kehadiran siswa. Kegiatan memotivasi siswa hanya dilakukan secara tersirat saja lewat kata-kata yang diucapkan guru saat mengecek kehadiran siswa, yaitu "Ibu tidak mau dengar lagi kalau ada yang tidak hadir terus keterangannya alpa ya. Pokoknya kalian harus rajin." Motivasi kecil tersebut cukup berpengaruh terhadap perilaku dan kebiasaan siswa untuk rajin datang ke sekolah. Seperti yang dikatakan oleh Sardiman (2012:74) bahwa motivasi akan menyebabkan terjadinya suatu perubahan energi yang ada pada diri manusia, sehingga akan bergayut dengan persoalan gejala kejiwaan, perasaan dan juga emosi, untuk kemudian bertindak atau melakukan sesuatu.

Guru langsung meminta siswa untuk melakukan presentasi mengenai pekerjaan kelompok pada pertemuan sebelumnya. Diskusi berjalan dengan baik karena setiap kelompok menyampaikan hasil kerja kelompoknya sesuai dengan perintah guru. Tugas yang diberikan guru berupa enam buah puisi rakyat dan siswa diminta untuk menganalisis berdasarkan struktur puisi rakyat serta menentukan jenis puisi rakyat tersebut. Hasil analisis setiap kelompok berbeda. Hanya terdapat dua kelompok yang dapat menentukan jenis puisi rakyat dengan benar sedangkan empat kelompok lainnya masih salah dalam menentukan jenis puisi rakyat. Setiap kelompok mempertahankan pendapatnya sehingga keadaan kelas cukup ricuh dan saat itulah peran guru sangat penting. Setelah semua kelompok selesai menyampaikan hasil analisisnya, guru menyimpulkan jenis puisi rakyat yang didiskusikan tersebut. Guru kembali mengulas jenis-jenis puisi rakyat berdasarkan strukturnya sehingga siswa lebih paham lagi.

Setelah kegiatan presentasi selesai, guru meminta siswa untuk menulis dua buah pantun karya tulisan siswa itu sendiri. Tugas ini berkaitan dengan keterampilan menulis siswa. Guru dapat melihat apakah siswa tersebut sudah memahami 
mengenai pantun atau belum melalui tulisan siswa tersebut.

Sebelum guru meminta siswa untuk menulis pantun, guru mengulas kembali secara singkat mengenai materi pantun yang sudah diajarkan pada pertemuan sebelumnya berupa pengertian pantun, ciri-ciri pantun, jenis-jenis pantun. Guru meminta siswa menulis pantun dengan jenis pantun bebas sesuai keinginan siswa supaya dalam mengungkapkan gagasannya mudah jika hal tersebut sesuai kemauan dan tanpa paksaan.

Siswa terlihat sangat antusias dalam mengerjakan tugas menulis pantun ini. Hal tersebut terlihat ketika guru selesai memberi pengarahan, siswa langsung mengerjakan tugas menulis pantun tersebut. Siswa juga banyak bertanya mengenai tugas menulis ini sehingga keaktifan siswa sangat terlihat. Selama siswa mengerjakan tugas menulis pantun, guru mengawasi proses siswa mengerjakan tugas individu ini. Setelah jam pembelajaran selesai, guru kemudian meminta siswa untuk mengumpulkan tugas tersebut. Guru kemudian menutup pembelajaran dan melakukan refleksi kepada siswa untuk melihat apa yang sudah diperoleh oleh para siswa mengenai teks pantun.

Berdasarkan hasil penelitian mengenai penilaian guru terhadap hasil tulisan pantun siswa kelas VII 2 di SMPN 3 Kota Bengkulu, guru melakukan penilaian kepada siswa dengan mempersiapkan bahan-bahan yang akan digunakan untuk diberikan kepada siswa. Guru menyesuaikan dengan tujuan pembelajaran yang harus dicapai. Guru menganggap bahwa penilaian terhadap pencapaian hasil belajar siswa merupakan hal yang sangat penting. Hal tersebut sejalan dengan pendapat Fathoni dan Riyana dalam Ruhimat (2013:168) bahwa evaluasi menurut syarat-syarat psikologis bertujuan agar guru mengenal siswa selengkap mungkin dan agar siswa mengenal dirinya seutuhnya. Di samping itu, evaluasi juga berguna untuk mempertinggi hasil pengajaran, karena itu evaluasi tidak bisa dipisahkan dari belajar mengajar, dan intinya adalah evaluasi belajar dengan tujuan untuk memperbaikinya. Evaluasi harus dilakukan oleh semua yang bersangkutan, bukan hanya guru tapi juga siswa sendiri, evaluasi harus ditinjau dari keseluruhan.

Pelaksanaan penilaian yang dilakukan oleh guru menjadi suatu keharusan yang harus dilakukan setelah selesainya proses pembelajaran. Guru membuat penilaian untuk mengukur keterampilan siswa dalam menulis pantun. Guru telah melakukan penilaian yang objektif yaitu dengan membaca terlebih dahulu tulisan pantun siswa, kemudian dilihat krieria penilaian pantun, dan memberikan nilai sesuai dengan aspekaspek yang terdapat di dalam kriteria penilaian pantun. Hal tersebut sejalan dengan pendapat Fathurrohman (2015:435-436) yang mengatakan bahwa prinsip-prinsip penilaian yang harus diperhatikan oleh guru dalam melakukan penialaian sebagai berikut:

a) Penilaian pembelajaran hendaknya menjadi bagian integral dari proses pembelajaran. Artinya setiap guru melaksanakan proses pembelajaran ia harus melaksanakan kegiatan pembelajaran.

b) Penialaian pembelajaran hendaknya dirancang dengan jelas kemampuan yang harus dinilai, meteri atau isi bahan ajar yang diujikan, alat penilaian yang akan digunakan, dan interpretasi hasil penilaian.

c) Penilaian harus dilaksanakan secara komprehensif, artinya kemampuan yang diukurnya meliputi aspek kognitif, afektif, dan psikomotoris.

d) Alat penilaian harus valid dan reliabel. 
e) Penilaian pembelajaran hendaknya diikuti dengan tindak lanjutnya.

f) Penilaian pembelajaran harus obyektif dan adil sehingga bisa menggambarkan kemampuan siswa yang sebenarnya.

Penilaian dilakukan oleh guru untuk menilai kemampuan siswa dalam menulis pantun. Untuk dapat menulis pantun, siswa diberikan pengetahuan terlebih dahulu mengenai pantun kemudian diberikan tugas menulis pantun untuk melatih keterampilan siswa dalam menulis pantun. Tulisan pantun siswa tersebut dinilai oleh guru. Hal tersebut sejalan dengan pendapat Daryanto (2014:114) tentang penilaian otentik dalam kurikulum 2013 bahwa penilaian otentik merupakan suatu bentuk tugas yang menghendaki peserta didik untuk menunjukkan kinerja di dunia nyata secara bermakna, yang merupakan penerapan esensi pengetahuan dan keterampilan. Penilaian otentik juga menekankan kemampuan peserta didik untuk mendemonstrasikan pengetahuan yang dimiliki secara nyata dan bermakna. Kegiatan penilaian tidak sekedar menanyakan atau menyadap pengetahuan, melainkan kinerja secara nyata dari pengetahuan yang telah dikuasai sehingga penilaian otentik merupakan penilaian yang dilakukan secara komprehensif untuk menilai mulai dari masukan (input), dan keluaran (output) pembelajaran.

\section{PENUTUP}

\section{Simpulan}

Berdasarkan hasil penelitian dan pembahasan di atas, maka dapat disimpulkan bahwa pelaksanaan pembelajaran menulis teks pantun pada siswa kelas VII 2 di SMPN 3 Kota Bengkulu dilaksanakan dengan pendekatan saintifik. Langkah-langkah pembelajaran yang dilakukan guru sudah sesuai untuk mencapai tujuan pembelajaran sesuai dengan Rencana Pelaksanaan Pembelajaran (RPP). Metode yang digunakan guru dalam proses pembelajaran sudah sesuai dengan yang ada di RPP dan bervariasi, yaitu tanya jawab, diskusi, inkuiri, dan penugasan. Namun, guru kurang memanfaatkan penggunaan media dalam proses pembelajaran. Meskipun demikian, siswa terlihat cukup aktif mengikuti pembelajaran.

Pelaksanaan penilaian yang dilakukan oleh guru diawali dengan memberikan petunjuk untuk mengerjakan tugas terlebih dahulu, kemudian guru meminta siswa untuk menulis pantun, siswa mengerjakan tugas dari guru dan tugas tersebut dikumpulkan oleh siswa. Guru membaca tulisan pantun siswa tersebut dan menilai berdasarkan kriteria penilaian yang terdapat di Rencana Pelaksanaan Pembelajaran (RPP). Berdasarkan penilaian tersebut diperoleh nilai rata-rata kelas sebesar 76,5.

\section{Saran}

Berdasarkan kesimpulan di atas, maka beberapa saran yang dapat dipertimbangkan untuk pembelajaran menulis pantun yaitu:

1. Bagi sekolah untuk menyediakan media agar pelaksanaan pembelajaran berjalan dengan baik.

2. Bagi guru supaya dapat lebih kreatif membuat media pembelajaran yang tidak tersedia di sekolah supaya pembelajaran tetap berjalan efektif dan dapat mencapai tujuan pembelajaran dengan baik.

3. Bagi siswa supaya dapat mengikuti pembelajaran dengan serius dan menggunakan waktu sebaik-baiknya dalam mengerjakan tugas yang diberikan oleh guru. 
DAFTAR PUSTAKA

Abidin, Yunus. 2012. Pembelajaran BahasaBerbasis Pendidikan Karakter. Bandung: PT Refika Aditama.

Daryanto. 2014. Pendekatan Pembelajaran Saintifik Kurikulum 2013. Yogyakarta: Gava Media.

Fathurrohman, Muhammad. 2015. Paradigma Pembelajaran Kurikulum 2013 Strategi Alternatif Pembelajaran di Era Global. Yogyakarta: Kalimedia.

Hasibuan dan Moedjiono. 2006. Proses Belajar Mengajar. Bandung: PT Remaja Rosdakarya.

Ismawati, Esti. 2013. Pengajaran Sastra. Yogyakarta: Ombak.

Kurniasih, Imas dan Berlin Sani. Sukses Mengimplementasikan Kurikulum 2013 Memahami Berbagai Aspek Dalam Kurikulum 2013. Kata Pena.
Mulyasa, E. 2013. Implementasi Kurikulum Tingkat Satuan Pendidikan. Jakarta: PT Bumi Aksara.

Priyatni, Endah Tri. 2014. Desain Pembelajaran Bahasa Indonesia Dalam Kurikulum 2013. Jakarta: Bumi Aksara.

Ruhimat, Toto dkk. 2013. Kurikulum \& Pembelajaran. Jakarta: Rajawali Pers.

Sanjaya, Wina. 2014. Penelitian Pendidikan Jenis, Metode dan Prosedur. Jakarta: Kencana Prenada Media Group.

Sugiyono. 2014. Metode Penelitian Kuantitatif Kulitatif dan R\&D. Bandung: Alfabeta. 